\title{
Analyzing the Political Speeches of Obama on "Race and Economic Renewal in America" in the Light of the Theory of Conversational Implicature
}

\author{
Ph.D. Igwedibia, Eugenia Adaoma \\ Department of English and Literary Studies, University of Nigeria, Nsukka
}

Doi:10.5901/mjss.2016.v7n3s1p253

\begin{abstract}
Interaction can take many dimensions such as face to face conversation, body language, written speeches, and so on. In almost every speech (spoken or written), the speaker or writer, in most cases, is the manager of his words. He controls and manipulates his words as he likes. In doing so, the speaker or writer puts information across to the listener or reader. The use of language in speech making is very important. The way language is used makes the speech meaningful to the listener. It is, therefore, necessary to look into the use of language in speech making. As far as this research is aware, not much has really been done in this area. Scholars and researchers focus their attention more on literary works than speech making. Political speeches have been severally made in various dimensions, and most of them have also been analyzed in one way or another. However, such speeches as Obama's political speeches on "Race and Economic Renewal in America" have been, in most cases, analyzed in terms of theory and practice. Speeches are supposed to be studied and interpreted using suitable apparatuses. Obama's speeches on "Race and Economic Renewal in America" definitely have pragmatic implications, but unfortunately have not been exhaustively discussed. This paper, therefore, attempts to analyze Obama's political speeches on "Race and Economic Renewal in America" within the frame work of pragmatics theory of Conversational Implicature.
\end{abstract}

Keywords: Conversational Implicature; Race and Economic Renewal in America; Political speeches; Language; Speech making.

\section{Introduction}

To appreciate the success or otherwise of President Obama's speech is to determine those factors in the speeches which have enabled him to configure the American world before the Americans. According to Monsuld (2007: 154), "To determine the way we perceive the world through discourse is to possess the decisive instrument of affecting control." This is what Foucault termed the "game of Truth." By game, Foucault (1994:80) means "a set of procedures that lead to a certain result, which as basis of its principles and rules of procedure may be considered valid or invalid, winning or losing." In pragmatics, it is widely held that the reality we perceive is a creature of the world. In using the world to create the desired reality, the veil of discourse is suspended between our faculties of perceptions, by metaphorical extension, expands or narrows down the possible versions we may have of the real world. Since this paper attempts to analyze the political speeches of Obama, there is a need for one to understand the relationship that exists between language and politics. To do this, it is important to refer to the view expressed by Anthony Paul Chilton (2004:20) that politics is "the art of governance and power" while language is "the universal capacity of humans in all societies to communicate." Politics as we know is a struggle for power in order to put certain political, economic and social ideas into practice (Bayram, 2010). Political power has to do with the position of being in charge over people's behavior, making decisions and controlling of general resources of society.

For one to assume this position, a type of language is needed. Language use or the use of language plays a very significant function in playing politics. Despite the crucial role language plays in politics, Fairclough (2012:1) contends that language can "misrepresent as well as represent realities, it can weave visions and imaginations which can be implemented to change realities and in some cases improve human well-being but it can also rhetorically obfuscate realities and construe them ideologically to serve unjust power relations." This simply implies that effective use of language in playing politics can bring about democratic dividends or achieve the reverse. For Taiwo (2007:92), language "conveys power. It moves people to exercise the franchise, debate and even revolt. It is, therefore, a central explanation of political stability or polarization." This shows that language is a vital tool in the implementation of successful democratic rule in any country. Wittgenstein (:44) posits that "the meaning of language depends on the context of use." For him, language used in ordinary life constitutes a language game which holds that language user follow certain rules for accomplishing verbal acts.

The office of the president is the highest political office in any country. It therefore, needs to be in constant touch 
with the people and this can only be made possible through speech making. It important these days to know that politics has now become a linguistic affair while language has become a political issue (Ayeomoni and Akinkuolere, 2004).

The use of language in political speech and the way in which it is used so as to make the speech meaningful to the hearer is a very important enterprise that must be ventured into. This reason has prompted the researcher to explore the theory of Conversational Implicature in "Race and Economic Renewal in America." The lacuna which this work recognizes is that the theory of

Conversational Implicature has not been explored in Obama's two selected political speeches under the present study.

\section{Objective of the Study}

The objective of this paper is to examine Obama's speeches to determine the discursive ingredients which have propelled them, against all odds, to such huge success as to winning the American Presidency. In so doing, to achieve an effective analysis, it is necessary to rely on principles of pragmatics, literary stylistics and analogical mapping. The speeches have touched an almost all aspects of life and woven around American history and in such captivating language that eclectic approach is considered most appropriate.

\subsection{Statement of the Problem}

A lot may have been done about political speeches of Obama, but to the knowledge of this researcher, there seems to be a little evidence of the aspect of pragmatics in this regard.

\section{Theoretical Framework/ Methodology}

\subsection{Conversational Implicature}

Conversational Implicature in pragmatics is all about how we understand an utterance in conversation in line with what we expect to hear. As Mey (2001:46) observes, ". . . if we ask a question, a response which, on the face of it, doesn't make 'sense' can very well be an adequate answer." He used the following as an illustration: if a person asks me:

\section{What time is it?}

It makes perfectly good sense for me to answer:

The bus went by in a particular context of conversation. This context should include the fact that there is only one bus a day, that it passes by our house at $7.45 \mathrm{am}$ each morning, and furthermore, that my interlocutor is aware of this and takes my answer in the spirit which it was given, viz, a hopefully relevant answer.

To know what people mean, you have to interpret what they say. The problem with interpretation is that misunderstandings are always possible. Hence, Leech (1981:30-31) remarks that "interpreting an utterance is ultimately a matter of guesswork, or (to use a more dignified term) hypothesis formation." Grice (as cited by Grundy, 2008:95), argues that "speakers should intend to be cooperative when they talk. According to him, one way of being cooperative is for a speaker to give much information as is expected." Grice formalized his observation that we should be cooperative when we talk into what he called "Cooperative Principle." This principle holds that you make your conversational contribution such as is required, at the stage at which it occurs, by the accepted purpose or direction of the talk exchange in which you are engaged. Within this principle, Grice proposes four maxims as follows:

Quantity: This means that you make your contribution as informative as is required. For instance, "some of the robbers have been arrested." This gives the implicature that not all the robbers have been arrested (by quantity). It also means that you do not make your contribution more informative than is required.

Quality: Here, you make your contribution one that is true. Do not say what you believe to be false, and do not say that for which you lack adequate evidence.

Relation: This means that you should be relevant.

Manner: This means that you should be perspicuous. Here, you avoid obscurity of expression and ambiguity. You should be brief (avoid unnecessary prolixity) and orderly. According to Grundy (2008:97), "The four maxims enjoin speakers to be informative to the expected degree (quantity), to say things that are well founded (quality), to be relevant (relation) and to be clear (manner)." These maxims are known to both the speakers and hearers; hence, the latter infer 
meanings that are conveyed but not stated. For instance, if my friend sips a glass of wine and says, "That is it," I would infer that the wine is good. Kempson (1975) outlined five characteristics of the cooperative principle and the maxims therein as follows:

(a) Conversational implicature are dependent on the recognition of the cooperative principle and its maxims.

(b) They will not be not be part of the meaning of the lexical items in the sentence.

(c) The implicature of an utterance will characteristically not be the sole possible interpretation of the utterance.

(d) The working out of an implicature depends on the assumption about the world which the speaker and the hearer share.

(e) The assumptions and implicature are cancellable.

Although Kempson's procedure seems to be unique, Onuigbo (2003:12) notes that "these characteristics do not provide any information radically different from the original approach." He pointed out that characteristic number five which talks about the assumptions and interpretations being cancellable is not in any way different from Grice's position that communication and interpretation are intelligent activities which we arrive at by a reasoning process called "interference to the best explanation." He, however, acknowledged Kempson's emphasis on the fact "that in actual use, sentences will not be restricted to an interpretation by the form and meaning of the sentence itself." Levinson (1983) has thrown more light on the nature and power of pragmatic explanations of linguistic phenomena. He stated that, it is possible to mean more than what is actually said. According to him, the apparent sharp difference between logic and natural language vanishes as soon as pragmatic implications are taken into account in text analysis.

From the on-going, it can be clearly seen that the cooperative principles and the conversational maxims are the central tenets of the theory of implicature, especially as enunciated by Grice. As Grundy (2008:97) observes, "the implicture . . . arise because the addressee assumes that the speaker is abiding by Grice's maxims, that is, the contribution is as informative as is possible, is well founded, is maximally relevant in context, and is to be read in a way that assumes perspicuity."

However, he also noted that the addressee probably has the thought already gone through his mind that speakers do not always abide so rigorously by these maxims. Hence the maxims are sometimes flouted. He points out that the headline of a fashion magazine feature article:

\section{"Brown is the new black as far as shoes are concerned"}

Clearly obscures and so flouts the maxim of MANNER.

In such a situation, we just have to provide a little more of the context ourselves and do a little more reasoning than would have been necessary had the speaker abided by the maxim.

The point being made clear here is that even when speakers flout the maxims, implicatures still obtain. This is because the hearer takes it that the speaker is essentially cooperative, in spite of flouting a maxim, and so must be intending to convey an implied meaning.

Considering our day to day language, it is obvious that some self-evident statements, regarding their truthfulness or falsity, have to be uttered for some to look for an implicature.

For instance, the statement "I am a man" is self-evident true, when it is spoken by a man and, therefore, flouts the maxim of QUANTITY. If it is spoken by a woman, then it is self-evidently false, and so flouts the maxim of QUALITY. Such self-evidently true or false statement are a signal to the hearer that there is need to look for an implied meaning. This is because there is what Grundy (2008) calls hedging maxims. Hedges are used by speakers to inform the hearer of the extent to which they are abiding by the maxims. For instance, in the statement "They say cigarettes are bad for you," "they say" should be understood as a hedge on the maxim of quality. This serves as a warning to the addressee that the speaker's information might not be as well founded as would normally be expected.

Generally, hedges do not add truth value to the utterances because they are attached to them. They are more of a comment on the degree or extent to which speaker is abiding by the maxims which guide contributions to conversation than a part of the utterance or what is conveyed. The implication here is that we not only send messages as we talk, but also regularly "inform each other how informative, well founded, relevant and perspicuous these messages are" (Grundy, 2008: 101).

In summary, all that has been said point to the truth that the principles provided by Grice to guide our utterances in conversation do really exist and that speakers orient themselves to these principles. Hence the employment of hedges. The application of the theory of Conversational Implicature to Obama's two political speeches under this study allows us to see how language is used in interesting and social ways. It also allows us to use words and give them inferred elements such as power aspects, because Obama's audience is aware of his social standing. Similarly, his language can 
act in ideological ways to reinforce American societal values. The two speeches under the present study require more than a semantic analysis to reveal the intended meaning of the words and phrases. This study rests on the assumption that these speeches are about the intersection of language and power, just as they underscores or exemplify the important areas of pragmatics. The implicit understanding of a power relationship between, for instance, two speakers in an interlocution, is often indicated by the meaning implied by the language used. And this meaning can be very contextdependent. For Grice (1975:26), meaning and intention are never explicit and transparent; they can only be recovered, thanks to the implicit elements. Obama's speeches have not been sufficiently subjected to detailed pragmatics analysis of the kind intended by this study.

\section{Analysis}

\subsection{Race in America}

\subsubsection{The Synopsis}

In this speech, Obama tried to, and did so successfully, tackle the issue of racism in America. The speech was a reaction to the allegation that he shared the same views with his pastor, Reverend Jeremiah Wright, a pastor of the Trinity United Church. He preached what was considered in some America circles as fiery sermons which were critical of Washington. He condemned the American foreign policy, which attracted the September 11, 2001 attacks, blamed the Washington government for the plight of the black American children and denounced the government for AIDS virus against African Americans.

The speeches were constantly repeated in the internet and in the media at a time when American electioneering campaigns were hotting up. Mr. Obama, emerging from a low historical background and aspiring to the highest political position in the land, his adversary thought that he shared the same views with his pastors and used it to make him unpopular.

On March 18, 2008, Mr. Obama (as he then was) addressed the issue. He talked on a lot of issues, each hyphenating the other but all bordering on racism in America. In the end, he convinced all that racism was real in America that it was a phenomenon passed on apocryphally from generations past and that Rev. Wright was part of the history, which ultimately shaped his views. He, however, condemned his views not because they were not well founded but because he did not appreciate that achievements have been made and that America had growing prospects of change.

He further shared the sympathy of the white middle class who saw the other American stocks as taking the opportunity meant for them. He heaped the blame of such white discrimination as the failure of the government to cater for their welfare and assured them of meaningful future. He also blamed successive governments of engendering the racist divided and forged allegiance among all the discriminated Americans. In the new allegiance, race should be treated as secondary problem because if the welfare of everybody is well taken care of, based on equity and justice, races will accommodate each other.

Finally, he drew a road map for a visionary mission of America that was vital of the movement in his theory of "not this time." "Not this time" rejects, all the philosophies which hold one American against the other in the continued attempt of the privileged few to enjoy a stupendous opulence while distracting the majority poor from uniting against a common problem for the general good.

\subsection{The Gricean Principle Applied to Race in America.}

\subsubsection{The Principle}

The principle underlying the speech on racism in America is forced by Obama's usage of language which hoists his perspective on the reader. Pragmatics principles, by communicative implicature, enable interpretations which derive truism that speakers or interlocutors often communicate more than they set on to do (Leech, 1981:142-157). As regards, "Race in America," Obama uses language so adroitly that a whole range of snippets of American history is, bounded in the speech, yet the whole history is anchored on the subject matter of the discourse, racism.

Every living man engages in communicative activities and it is indeed impossible not to do so (Watzlawick, 1967:4). Obama lives out of this pragmatics principle in his electioneering campaign. What makes his speech on racism spectacular is that he did not only communicate but went beyond the frontiers of everyday communication to weave in uncommon features of everyday communication that turned the speech into an emotional yet educative manifesto that 
people embraced him despite his mean history as an immigrant black contesting for the highest position in America and the most powerful position in the world. Mr. Obama rather than suppress this perceivable handicap, discusses it to disarm the oppositions who may use it to their advantage. This relates to what (Gazdar, 1980:49-68) calls "Scalar implicature."

\title{
4.2.2 Scalar Implicature
}

Interlocutors often communicate what they would have otherwise suppressed (Gazdar, 1980). This implicature can be said to be the theme of the speech "Race in America." Mr. Obama is compelled by the impending election, which offers with it the possibilities of change to scale America into compartments of social class, which ordinary would be suppressed for fear of insurrection and public disorder. Mr. Obama starts from himself.

\author{
I am the son of a black man from Kenya and a white woman \\ from Kansas... I am married to a black American who carries \\ within her the blood of slaves and slave owners - an \\ inheritance we pass on to our two precious daughters.
}

He presents his background as demeaning and for the interest of those who may not know or use it against him in public and the rumour mill. The effect was not to exploit it for political reasons.

Mr. Obama highlighted this when he noted that "it's a story that has not made me the most conventional candidate" (Olive, 2008:256). He did also highlight the greatness of America which offers opportunities for every American, who can, to make change possible:

\begin{abstract}
I have brothers, sisters, nieces, nephews, uncles, and cousin, of every race and every hue, scattered across three continents and for as long as I live, will never forget that in no other country on earth is my story even possible.
\end{abstract}

The scale visibly weighed against him, but for such humility and the will anchored on clear policies to serve, Americans where enthused. It forcefully impacted on them positively and pragmatically next to the black Americans whether immigrants or ex-slaves are the segments of the white community labelled working class, or middle class white Americans who have not been privileged by fellow white Americans who control government. This class feels strongly about their condition. Theirs (working and middle-class white Americans) is the immigrant experience:

\begin{abstract}
as far as they're concerned no one's handed them anything, they've built it from scratch. They have worked hard all their lives, many times only to see their jobs shipped overseas or their pensions dumped after a life time of labour. They are anxious about their future, and their dreams slipping away...
\end{abstract}

The Latinos and Asians were scaled but not topically in the speech. The highest up the scale are the few men and women who control power metonymically, referred to as Washington. Washington is dominated by lobbyists and special interest groups.

The scale identified races but, put together, they resolved themselves into two social classes: the rich and the poor. The scaling of Americas proved to them, both white and black, that multiplicity of races was not the problem. The problem was the manipulation of the rich few against the majority poor, a manipulation which can only be resolved by a concerted action which will force the few to attend responsibly to the needs of the majority of Americans.

Again, the scaling made it possible for Americans, especially the dispossessed, to forge alliances to change the manipulative tactics of Washington, which distract them by using race and racism as a means to their own needs.

\subsubsection{Communicative Principle}

In the speech of Obama under review, a typical communication chain is not visible even though it can be understood. Watzlawick, (1967) contends that is impossible for anyone not to engage in communication. By the implicature of communication, in communicating, the interlocutors often mean more than what they say (Leech, 1981).

The communicative implications of the above claims are many. By the contention that people engage in communicative activity, it is assumed that community is a bilateral activity.

Though it is possible for a person to communicate with himself, it is usually an activity involving two or more 
persons. Obama talked to, rather than communicate with, the Democrats on Racism in America. The nature of the communicative event makes it so. First, being a public speech, it is usual that turn_talking, which characterizes discursive events is absent.

Secondly, being a public speech, whose primary aim is to convince, Obama said certain things he would have ordinary suppressed. This contention is a conscious effort to expose the genuine yearnings of the ordinary American who has the power to exercise his franchise in the election but not how political power is wielded. Therefore, Obama used the scalar implicature of the American society to systematically inform the Americans of the causes of evil in society. This is opposed to Gazdar (1980) who assumes that speakers do so unconsciously in order to communicate what they would have ordinarily suppressed.

Obama lives out the axiom of communicative principle which stipulates that when communicating, speakers want to be understood clearly. His speech adapts well to the "strength scale" of many expressions, found in the speech. The following outlines how Obama's speech adapts to strength scale of expression enunciated by Levinson (1983).

In the speech, some pragmatic force is attached to the choice of certain qualities to include or exclude some segments of America from responsibility which has resulted in the commission or omission of the neglect in issue. The strength scale is identified with such markers as all, most, many, few, none, etc. as shall be seen, all is inclusive, many excludes all, some/many is vague while few connotes a weak percentage of the population on the scale of the act on omission. The following markers are present in Obama's speech under discussion:

\section{I have chosen to run for presidency ... because I deeply believe that WE cannot solve all challenges of the time unless we solve them together.}

In the above excerpt, WE is inclusive of all American. Whether white, black, Asian, Hispanic, Native Americans, etc. WE excludes NONE.

In comparing himself to others who have listened to sermons, which are disapreceable, Obama did not include everyone when he used many:

Just like many of you have heard remarks from your pastors priests or rabbis with which you strongly disagreed.

Here, the use of MANY excludes ALL. The use of MANY does not commit the speaker in associating the attribute with every listener, though there is such a possibility. Furthermore, the listener does not know for certain whether what is true of him is also true of the other members of the audience.

Mr. Obama selected segments of society to make his point. This is seen in the following excerpts:

There will no doubt be those for whom my statements of condemnations are enough.

The use of THOSE in this context signifies NOT ALL. This style of addressing SOME rather than all at a time may be seen in the use of negatives, e.g.

That isn't all. I know of the man (Rev. J. Wright).

The use of NOT ALL shows that the evidence already provided is a part of the whole. Sometimes, he weighs the sentiments unevenly to show the narrower of some segments of the population who condemns on the basis of prejudice.

WE can dismiss Rev. Wright as ... some have dismissed

Geraldine Terraro.

The use of SOME here indicates part of WE who join others in condemning Wright, but not Terraro, on the basis of prejudice. Sometimes, Obama used part of a part to illustrate a given point.

(To all those who scratched and clawed their way to get a

piece of the American Dream, there were many who didn't make it).

ALL THOSE is part of whole which excludes ALL; however, the all is not included in the use of MANY. This is why Levinson claims that the use of MANY refers to a vague number, especially here that it refers to partitives and 
subpartitives of a number.

Obama appealed to the majority by informing them that the American racism is hoisted on the interest of the few in Washington who manipulate the majority by appealing to divisive tendencies such as racism to cover their failing.

\subsection{Economic interest that Favours the Few over the Many}

The use of FEW over MANY divides the population into some misguided arrangement where the majority who should call the shots turn out to the victims of continuing injustice.

\subsubsection{Cooperative Principle}

This Gricean principle contends that the facts upon which communication is based are founded on mutually accepted pragmatically determined context. The Obama speech on racism lives out the maxims of the cooperative principle.

18

On the maxim of quantity, the contribution of the speech provided the needed information based on the evidence which Mr. Obama has. By making allusion to illustrate his points, he furnished evidences, which regulated the truth of the claims. Some of the allusions include the Philadelphia convention of 1787, the history of slavery, the contribution of the United States, Obama's Kenya's ancestry, the World War 11, the protests sparked off by Rosa Park's bus protest, the legacy of Jim Crow, the sermons of Rev. Wright, the death of Martin Luther King, etc. indeed, Obama gave every claim of his ample evidence to support its veracity. He, therefore, fulfils the maxim of quality as enunciated by Grice. The evidence provided above with his campaign manifesto, relates to the history of America, the statement of racism and the ambition to become president.

The maxim of manner, is also fulfilled by Obama's use of what in popular parlance is called the English of is and was. The combinations of niceties of pragmatic discourse in the speech sold to America the World and the fact that from his disadvantaged background, he became American president is sufficient evidence that this speech was perspicuous and assimilated by America. In the end, he saved the face of Rev. Wright, all Blacks, and the Oppressed Whites, and forged an alliance against the intrigues of Washington.

\subsubsection{Economic Renewal}

Mr. Barack Obama's speech on Economic Renewal was delivered on March 20, 2008, at Charleston, West Virginia. In this speech, Obama lamented the cost of Iraq-war. This war, according to him, has diverted America's attention from fighting the genocide in Darfur, energy crises, global warming, disease, nuclear weapons, climate change and terrorism, particularly the al Qaeda in Afghanistan and Pakistan, which constitute the crucial challenges of the twenty-first century.

The focus of the speech was on the toll which Iraq-war has taken on America's economy and how to address the situation. He graphically narrated how ordinary Americns are paying a price for war, both individually and collectively, thus:

\footnotetext{
When you're spending over fifty dollars to fill up your car because the price of oil is four times what it was before Iraq, you're paying a price for this war. When Iraq is costing each household about one hundred dollar a month, you're paying a price for this war. When a National Guard unit is over in Iraq and can't help out during a hurricane in Louisiana or With floods here in West Virginia, our communities are Paying a price for this war. (Olive, 2008: 289).
}

The above price being paid by individuals, families and communities is a reflection of the price that America is paying. By the time Obama was making the speech, a conservative estimate shows the cost of the war so far stood at half a trillion dollars. Besides the World War 11, Obama state that no other war has cost so much in human history. His forecast was that by the time the war would be over, the cost would reach three trillion dollars.

The Americans were initially told that the cost of the war would be fifty to sixty billion dollars, and that reconstruction would pay for itself out of Iraqi oil profits. Obama affirmed that like so much else about war, Washington did not tell the American the truth. The cost of the war have also been compounded by its careless and incompetent execution. 
Due to the effects of the Iraq-war, soldiers at Fort Drum had to wait longer than a month to get their mental health screening. Along the same line, Obama blamed George W. Bush for authorizing the war as well as giving tax cuts to the rich in a time of war. He also blamed John McCain for now supporting those tax cuts which he opposed as unfair and fiscally irresponsible.

To drive the message home, Obama stated that because of the Bush-McCain policies, America's debt had ballooned, thereby creating a fragile economy for the nation. This, if not urgently addressed, would place an unfair burden on American children and grandchildren who will eventually have to pay the debt. He further asserted that the price being paid for the war had led to getting a loan from China, which is detrimental to America's economy, global leadership and national security.

Mr. Obama reiterated his opposition to the war from the start. Back in 2002, he had said that the war could lead to an occupation of Iraq not just of undermined costs. Hence he insisted that the war should have never been authorized and never been waged.

Proffering solutions to the already created problems and restructure the economy, Obama made it clear that when he became president, he would ensure that American troops would have the equipment and support they needed. Moreover, he would bring the war to an end. He stressed that instead of fighting the war, Americans could be fighting to rebuild their roads and bridges, to free themselves from tyranny of oil, to invest in sources of energy, to create jobs, to rebuild the military which has been stretched to its limits by the war, to ensure the future of the American children, to secure their homeland and stop world's most dangerous weapons from falling into terrorist hands, to ensue opportunity, equality and prosperity in the land, to put the American dream within the reach of every American dream within the reach of every American, and to make health care a reality in the country.

In conclusion, Obama challenged the Americans to make use of the chance to be offered by the election to reclaim their future:
To end the fight in Iraq and take up the fight for good jobs and universal health care. To end the fight in Iraq and take up the fight for a world-class education and retirement security. To end the fight in Iraq and take up the fight for opportunity, and equality, and prosperity here at home (Olive,2008: 294).

\subsubsection{Grice's Principle and Obama's Speech on Economic Renewal}

In almost every utterance, the audience can distinguish between what is said on the one hand and what is meant and not said on the other. The context of the speech is very important in determining what the speaker means by what he says. Again, according to Grundy (2008:95), "knowing the speakers well enough would enable us to know what they each mean" by what they say.

Any meaning that is conveyed indirectly or through hints, and understood as implicit in what is said without actually being explicitly stated, is an implicature (Grice, 1975). Due to this implicature, Grice argues that speakers intend to be cooperative when they talk. So, how Obama in his speech on Economic Renewal in the light of the cooperative principle in its maxims of quantity, quality, relation and manner?

Did Mr. Obama make his speech as informative as was required, or more informative than was required? This question concerns the maxim of quantity. Obama's speech on Economic Renewal was an x-ray of the costs and implications of the Iraq-war on the American economy. Until that speech, majority of the Americans did not have all the required information on the issue. On that note, Obama's speech was as informative as was required. In this sense, the speech obeyed the maxim of quantity.

On the maxim of quality, Obama made effort to state the truth as he knew and believed, and was also able to provide evidence for his assertions. For instance, he believed and stated that the cost of the war is greatest for the troops and those who love them, and that the war has other financial implications. Thus he stated:

Somewhere in Baghdad today, a soldier is stepping into his Humvel ad heading out on a patrol. That soldier knows the cost of war... it is the cost of being kept awake at night by the whistle of falling mortars... of a heart that aches for a loved one back home, and a family counting the days until the next $R \& R$. It is the cost of losing a friend who asked for nothing but to serve his country. 
However, Obama, by making use of what Grundy (2008:100) refers to as "hedging maxims" did not fully abide by this maxim of quality. This is attested to by the following statement: some say the time cost is even higher and that by the time it's over, this could be a three trillion dollar war (Olive, 2008). "Some say" would be understood as a hedge on the maxim of quality and would serve as a warning to the addressees that the speaker's information might not be as authentic and well founded as would be expected. As Grundy (2008:101) states, "Hedges and intensifiers show that the guiding principles for talk suggested by Grice really do exist and that speakers orient reflexively to these principles as they communicate."

Regarding the maxim of relation, Obama's speech could be said to be relevant. One can take a look at the following questions that he posed:

\begin{abstract}
How much longer are we going to ask our troops to bear the cost of this war? How much longer are we going to ask our families and our communities to bear the cost of this war? When are we going to stop mortgaging our children's future for Washington's mistake? (Olive, 2008).
\end{abstract}

The questions are rhetorical, and have the implicature that the addressees should wait no longer. They were expected to take action now, by using the election as a chance to change the situation for the better. In this sense, the questions were relevant, thereby contributing to the fulfilment of the maxim of relation.

Finally, Mr. Obama was careful to avoid obscurity of expression and ambiguity. Efforts were made on his part to be straight, brief and orderly. This is indication of compliance with the maxim of manner which enjoins the speaker to be perspicuous. In this regard, Obama thus stated:

Yesterday, I addressed some of these other costs in a speech on the strategic consequences of the Iraq war. I spoke about how this war has diverted us from fighting al Qaeda.... And today, I want to talk about another cost of this war _the toll it has taken on our economy (Olive, 2008: 288-289).

In this speech, Obama did not leave his audience in doubt regarding his ideas, his stand on the issue of Iraq-war, and the focus of his presidency when elected. The state of the American economy was also clearly stated, and the road map towards its repositioning was articulated in unambiguous terms.

\title{
5. Conclusion
}

From the discussions carried out in this paper, it can be stated that Obama's speeches under the present study obeyed Grice's maxims to a great extent and flouted the same to a lesser extent. This has been observed from the analysis of his speeches in the light of the maxims of quantity, quality, manner and relation. According to Grundy (2008), every utterance has both natural meaning (entailment) and non-natural meaning (implicature), whether it abides by or flouts the maxims. He further states that flouting a maxim is a particularly salient way of bringing the addressee to draw an inference and thereby recover an implicature. In other words, flouting a maxim obviously alerts the addressee that there is an implicit meaning.

\section{References}

Akwanya, A. N. (2005). Language and habits of thought. Enugu: New Generation Books.

Akwanya, A.N. (2007). Semantics and discourse: Theories of meaning and textual analysis. Enugu: Acena Publishers.

Ayeomoni, M.O. (2004). A linguistic investigation of the Nigerian political elite. Ibadan: Hope Publications.

Bayram, F. (2010). "Ideology and political Discourse: A Critical Discourse Analysis of Erdogan's Political Speech." Retrieved from http://www.ARECLS.7. 23-40, 3 Sep. 2015.

Fairclough, I. \& Fairclough, N. (2012). Political discourse analysis: A method for advanced students. London: Routledge.

Foucault, M. (1994). "The Ethics of the Concern of Self as a Practice of Freedom." Ethics, Subjectivity and Truth: The Essential Works of Michael Foucault. Ed. Paul. Robinow. London: Penguin, 281-301.

Gazdar, G. (1980). "Pragmatic Constraints and Linguistic Production." Language Production. Ed. Brian Butterworth. New York: Academic Press, 142-157.

Grice, H. P. (1975). "Logic and Conversation." Syntax and Semantics: Speech Acts 3. Eds. P. Cole and J. Morgan. New York: Academic Press. 26-32. 
Grundy, P. (2008). Doing pragmatics. London: Hodder Education.

Kempson, R.M. (1975). Presupposition and the delimitation of semantics. Cambridge: Cambridge University Press.

Kempson, R.M. (1977). Semantic Theory. Cambridge University Press.

Leech, G. N., \& Short, M.H. (1981). Style in fiction: A linguistic guide to English fictional prose. London: Longman.

Leech, G.N. (1983), The principles of pragmatics. London: Longman.

Levinson, S. (1983). Pragmatics. Cambridge: Cambridge University Press.

Mey, J. L. (2001). Pragmatics: An introduction. Oxford: Blackwell.

Monsuld, S. (2007). "Literature as Discourse Illustrated in an Analysis of Discursive Strategies in Salman Rushdie's The Satanic Verses." Toward the Understanding of Discourse Strategies. Eds. M. Olateji, R. Taiwo, and F. Adeleke. Ago-Iwoye, Nigeria: Onabanjo University Press. 100-109.

Olive, D. (2008). Barack Obama's great speeches. Benin City: Beulahland publications.

Onuigbo, S. (2003). Exploration of the concept of conversational implicature in Ebele Eko's Bridges of Gold. Nsukka: University of Nigeria Press.

Paul, A.C. (2004). Analyzing political discourse: Theory and practice. USA: Rouledge.

Watzlawick, P., Helmick, B. \& Don, J. (1967). Pragmatics of human communication: A study of interactional patterns, pathologies, and paradoxes. New York: Norton. 